\title{
A Study on Udder Health Management Practices, Reproductive Disorders and Subclinical Mastitis in Buffalo Herds in Coastal Region of Bangladesh
}

\author{
Dibyendu Biswas $^{1, a, *}$, SM Hanif ${ }^{1, b}$, Eaftekhar Ahmed Rana ${ }^{2, c}$, AKM Mostafa Anower ${ }^{3, d}$ \\ ${ }^{I}$ Department of Medicine, Surgery and Obstetrics, Faculty of Animal Science and Veterinary Medicine, Patuakhali Science and \\ Technology University, Barishal Campus, Babuganj, Barishal-8210, Bangladesh \\ ${ }^{2}$ Department of Microbiology and Veterinary Public Health, Chattogram Veterinary and Animal Sciences University, Chattogram-4225, \\ Bangladesh \\ ${ }^{3}$ Department of Microbiology and Public Health, Faculty of Animal Science and Veterinary Medicine, Patuakhali Science and Technology \\ University, Barishal Campus, Babuganj, Barishal-8210, Bangladesh \\ *Corresponding author
}

\section{A R T I C L E I N F O A B S T R A C T}

Research Article

Mastitis is an economically important disease of intensive buffalo dairy farming worldwide. Detection of subclinical mastitis (SCM) is important for its management and control. The purpose of this study was to estimate the prevalence of reproductive disorders, SCM and udder health management practices in the buffalo dairy farms of Bhola District, Bangladesh. Data on animal

Received : 06/03/2020 Accepted : 07/05/2020 demographics, reproduction status, daily milk yield and status of California Mastitis Test (CMT) result were recorded. A total of 402 buffaloes were observed in two farms at Bhola district and among them 70 milking buffaloes were randomly selected for CMT. The overall prevalence of SCM in buffalo was $20.0 \%$. Young age group of buffaloes was more susceptible for SCM and it was not significant difference. Parity and stage of lactation have no any effect on SCM. However, abortion case was more susceptible to SCM than other diseases but not any significant difference. During milking the milkers never use any antiseptic solution for washing the udder and never use any feed supply during milking. Among the isolated organisms Staphylococcus spp. and E. coli were found more frequent in the study area and gentamicin and ciprofloxaclin were most sensitive to the isolated organisms. From this study it was concluded that buffalo's udder was very resistance to SCM infection and udder management practice was very poor. Common antibiotics were resistance to isolated organisms from SCM case. Gentamicin and ciprofloxacin were found more susceptible against all four isolated organisms.

Keywords

Buffalo

Udder Health

Reproductive Disorder Antimicrobial Sensitivity dipupstu2012@pstu.ac.bd (iD https://orcid.org/0000-0002-5834-6202 eaftekhar787@gmail.com

https://orcid.org/0000-0002-5834-6202
https://orcid.org/0000-0003-3648-1670 b@smhanifdvm7@gmail.com anower@pstu.ac.bd https://orcid.org/0000-0002-8762-5147 iD https://orcid.org/0000-0002-3704-4141

\section{Introduction}

Buffalo is one of the most important livestock species populated largely in tropical and sub-tropical countries (Das and Khan, 2010) and considered as 'black gold of south Asia' (Rabbni et al., 2010). The total buffalo population of Bangladesh is 1.457 million (DLS, 2015) of which coastal regions posses (Faruque et al., 1990) about $40 \%$. Most of the populations are reverine type with the exception of some swamp type found in Bangladesh. Dairy buffalo production has been a tradition in Asia especially in south Asian countries like Bangladesh, India, Pakistan and Afghanistan where fresh buffalo milk, cultured sour milk, ghee, yoghurt and special types of cheeses are of popular dairy products (Hamid et al., 2016). However, in Bangladesh the consumption of milk and meat was increased by at 4.0 and $12.7 \%$ during 2005-2010, respectively. The increasing demand due to its white color, high fat content and good flavor but milk yield per dairy buffalo is very low from 0.5 to $1.5 \mathrm{~L} /$ day upto $250-270$ days lactation period (Huque and Borghese, 2012). However, the Bangladesh has great opportunity to produce buffalo milk because of its high consumer demand. But, buffalo has never been addressed and always neglected species despite their important role in the national economy.

Optimum production and reproduction of buffaloes is the key success of dairy economics. The reproductive disorders of buffalo can lead to economic losses in term of reduce fertility, increased calving interval and medication cost and decreased milk production (Fareed et al., 2016). However, poor reproductive performance of the animals 
leads to economic losses due to reduced production and additional cost on health management (Inchaisri et al., 2010). Although the coastal area is very suitable for buffaloes rearing due to their natural wallowing behaviour as well as availability of pasture land and plenty of lushly feed because they can easily take this feed. A minimum management system is needed for their rearing in house and or farming condition. A limited study on socioeconomic status of buffalo farmers and reproductive performances was recorded at elsewhere (Amin et al., 2015; Siddiki et al., 2015). Therefore, sufficient information on reproductive performances with relation to milk production of buffaloes in coastal areas is very limited.

SCM, the most costly and drastic disease in the dairy industry and responsible for financial losses. It is argued that interaction of both extrinsic and intrinsic factors mainly responsible for bovine mastitis. However, apart from the micro-organisms, udder health management practice is the key factor for reducing the udder disease incidence. Though, the frequency of clinical or SCM in buffalo is less than the cow as may be the cause of udder morphology and low volume of milk is yielded in buffalos. On the other hand, number of organisms like as Staphylococcus spp., Streptococcus spp., Bacillus spp. and environmental organism E. coli are very frequently associated with SCM mastitis in buffaloes (Nahed et al., 2013). Early detection and urgent antimicrobial therapy of mastitis cases is absolutely essential for dairy farmers to reduce production losses (Abebe et al., 2016). About 18$40 \%$ of cattle and buffaloes were culled mainly due to mastitic problems (Ansari-Lari et al., 2012) which incriminate direct losses to the farmer as well as to the genetic resource. Therefore, establishment of valid data for reproductive disorders and udder health management (UHM) practices to support the scientific background for selection of the indigenous buffalos is an utmost important. Therefore, the present study was designed to investigate the prevalence of reproductive disorders, SCM of buffalo at the affected area and along with this investigated the applied udder health management practices of buffaloes in the coastal area and identify the organisms responsible for SCM of buffaloes.

\section{Materials and Methods}

The study was conducted at Bhola districts, Bangladesh from May to August, 2019. A total of 70 milking buffaloes were used in this study from 2 different buffalo farms. A structured questionnaire was developed and all data were directly collected from the farm owners by farm visits. Efforts have been made to avoid obvious mechanical error, while recording the data.

\section{California Mastitis Test}

A standard protocol and aseptic measurement was taken to collect milk samples from the farms. The milk was collected from all four quarters separately and tested onfarm by California Mastitis Test (CMT) kit (California Mastitis Test $\AA$, Portland) according to manufacture instruction. Briefly, a plastic paddle with four receptacles was used for this purpose. After cleaning the teats using antiseptic, $2 \mathrm{ml}$ of fore milk was stripped from 4 teats of each buffalo cow separately into the respective cup of the paddle. Equal amount of CMT reagent was added to milk in each cup of the plastic paddle. Then the reagent and milk were mixed in the cups of the plastic paddle by a swirling motion. The result was recorded immediately according to manufacture instruction by visual examination. No coagulation or gel formation of milk was regarded as negative for SCM and coagulation or gel formation of milk was regarded as positive for SCM. The positive milk sample was preserved at $-20^{\circ} \mathrm{C}$ for further molecular study and send to Department of Microbiology and Veterinary Public Health, Chattagram Veterinary and Animal Sciences University, Khulshi, Chattogram-4225 for further analysis.

\section{Bacteriological Analyses of Milk Samples}

For isolation and identification of bacteria, four common bacterial species were targeted in this experiment. CMT positive samples were used in this bacterial isolation experiments. The $20 \mu \mathrm{l}$ of milk sample was streaked on $5 \%$ bovine blood agar plate and incubated up to $72 \mathrm{~h}$ at $37^{\circ} \mathrm{C}$ and the plate was examined every $24 \mathrm{~h}$ interval for optimum growth of mastitic bacteria. Bacterial species were primarily identified based on colony morphology, presences or absences of haemolysis, gram staining, catalase and coagulase test. Subsequently, suspected Staphylococcal colonies were sub-cultured on mannitol salt agar (Oxoid Ltd., UK) and incubated for $24 \mathrm{~h}$ at $37^{\circ} \mathrm{C}$. Characteristic yellowish colony on mannitol salt agar, gram positive grape like cluster cocci with catalase positive isolates were identified as Staphylococcus spp. For, E. coli species the presumptive colony was inoculated onto MacConkey agar (Oxoid Ltd., UK) medium and incubated at $37^{\circ} \mathrm{C}$ for $24 \mathrm{~h}$. Large pink colonies yielded on the MacConkey agar were further subculture onto Eosin methylene blue (EMB) agar (Oxoid Ltd., UK), and after recommended incubation, only distinctive metallic green sheen colonies were confirmed as E. coli. For Streptococcus spp. all presumptive colony were subcultured onto blood agar and characteristic dew drop like colony with ring shaped hemolysis and, catalase negative, gram positive chain former cocci were identified as Streptococcus spp. Bacillus spp. were confirmed based on colony morphology (irregular, large, raised gray color colony) with characteristic hemolysis patterm and large gram positive bacilli with positive catalase test. All bacterial isolates were then preserved at $-80^{\circ} \mathrm{C}$ using $50 \%$ glycerol until further examination.

\section{Molecular Confirmation of Staphylococcus aureus and E. coli}

Two common bacterial primers were used in this experiments due to excessive cost of this primer namely, $S$. aureus and E. coli. Bacterial genomic DNA was extracted by using boiling lysis method described by Millar et al. (2000). Finally, Staphylococcus isolates and E. coli isolates were confirmed by the PCR amplification by the following primers (Table 1). The PCR amplification conditions were initial denaturation for $2 \mathrm{~min}$ at $95^{\circ} \mathrm{C}$, followed by 30 cycles for $30 \mathrm{~s}$ at $95^{\circ} \mathrm{C}, 35 \mathrm{~s}$ at $56^{\circ} \mathrm{C}$, and $60 \mathrm{~s} 72^{\circ} \mathrm{C}$; and final extension at $72^{\circ} \mathrm{C}$ for $2 \mathrm{~min}$. Finally, amplified PCR products were visualized in UV chamber after completing gel electrophoresis on $1 \%$ agarose. 
Table 1. Primers template used for the confirmation of Staphylococcus aureus and E. coli

\begin{tabular}{c|llc}
\hline \multicolumn{1}{c|}{ Organism name } & \multicolumn{1}{|c}{ Primer name } & \multicolumn{1}{c}{ Primer sequence } & Product size \\
\hline \multirow{2}{*}{ Staphylococcus aureus } & au-F3 & TCGCTTGCTATGATTGTGG & $359 \mathrm{bp}$ \\
& au-nucR & GCCAATGTTCTACCATAGC & 884bp \\
& uspA Up & CCGATACGCTGCCAATCAGT & $166 \mathrm{bp}$ \\
& uspA Down coli & ACGCAGACCGTAGGCCAGAT & \\
& uidA Up & TATGGAATTTCGCCGATTTT & \\
& uidA Down & TGTTTGCCTCCCTGCTGCGG & \\
\hline
\end{tabular}

Table 2. Overall prevalence of SCM in buffalo

\begin{tabular}{c|ccc}
\hline Total animal population & Total animals observed in this study & CMT positive & Prevalence $(\%)$ \\
\hline 402 & 70 & 14 & 20.0 \\
\hline
\end{tabular}

Table 3. Effect of age of animal on SCM prevalence in buffaloes

\begin{tabular}{l|cccc}
\hline \multicolumn{1}{c|}{ Age of animals (year) } & $\begin{array}{c}\text { Number of animals at } \\
\text { risk }\end{array}$ & $\begin{array}{c}\text { Number of affected } \\
\text { animal }\end{array}$ & Prevalence (\%) & Overall difference \\
\hline $1-5$ & 21 & 6 & 28.57 & \\
$>5-7$ & 25 & 5 & 20.00 & $\mathrm{P}=0.4049$ \\
$>7$ & 24 & 3 & 12.50 & \\
\hline
\end{tabular}

Table 4. Effect of parity on SCM prevalence in buffaloes

\begin{tabular}{l|cccc}
\hline \multirow{2}{*}{ Parity } & $\begin{array}{c}\text { Number of animals at } \\
\text { risk }\end{array}$ & $\begin{array}{c}\text { Number of affected } \\
\text { animal }\end{array}$ & Prevalence (\%) & Overall difference \\
\hline $1-2$ & 24 & 7 & 29.17 & \\
$3-4$ & 31 & 5 & 16.13 & $\mathrm{P}=0.3739$ \\
$>4$ & 15 & 2 & 13.33 & \\
\hline
\end{tabular}

\section{Antimicrobial Susceptibility Test}

All bacterial isolates were selected for culture sensitivity testing against 12 different antimicrobials compounds using disc diffusion methods according to Clinical and Laboratory Standards Institute (CLSI) guideline (CLSI. 2010). The following antibiotic discs (Oxoid Ltd., UK) were used, namely: enrofloxacin (10 $\mu \mathrm{g})$, ciprofloxacin $(5 \mu \mathrm{g})$, gentamicin $(30 \mu \mathrm{g})$, tetracycline (30 $\mu \mathrm{g})$, erythromycin $(15 \mu \mathrm{g})$, amoxicillin $(10 \mu \mathrm{g})$, trimethoprim-sulfamethoxazole $(1.25+23.75 \mu \mathrm{g})$ cefoxitin $(10 \mu \mathrm{g})$, ceftriaxone $(10 \mu \mathrm{g})$, vancomycin $(5 \mathrm{mg})$, penicillin (10 IU) and streptomycin $(100 \mu \mathrm{g})$. For each isolate, the zone of inhibition around each disc was measured and interpreted as susceptible (S), intermediate (I) and resistant (R) according to CLSI referred value of veterinary pathogens (CLSI. 2010).

\section{Statistical Analysis}

Descriptive statistical analysis was performed to assess the prevalence of reproductive diseases and disorders, risk factors of mastitis by SPSS 17 statistical software.

\section{Result and Discussion}

In the present study overall the prevalence of SCM was $20.0 \%$ (Table 2). The similar result was found the some studies (Srinivasan et al., 2013; El-Naker et al., 2015). SCM has been reported to be more important (5-20\% in buffaloes) than clinical mastitis $(1-10 \%)$ because it is 15 40 times more prevalent than the clinical form (Pankaj et al., 2013). However, subclinical form sometimes reduces the milk production in next lactation and enhances the chance of clinical mastitis.
There is no any significant difference of SCM within the different age groups (Table 3). Buffaloes with 1 to 5 years of age had highest $(28.57 \%)$ SCM while animals with until 7 years of age had lowest $(20.0 \%)$ SCM but more than 7 years of age the incidence was decreased to $12.5 \%$ and it was not significant different among these group). In another study it was reported that animals above 9 years of age were more prone to SCM than the younger animals (35 years) (Baloch et al., 2016). The present result was dissimilar with the previous result might be due to different geographical location. However, early parity stage was also the susceptible age of SCM in buffalo. But, there is no any significant different of prevalence of SCM among the different parity groups, whereas, the early parity had comparatively higher prevalence rate (Table 4). Other researches showed that higher parity has positive correlation with SCM (Kavitha et al., 2009) and recorded as a risk factor associated with SCM in buffalo (Baloch et al., 2016).

In table 5, it was found that non-pregnant buffaloes were more prone to SCM and it was higher than the pregnant buffaloes. However, there was no any significant difference but proportionately the incidence of SCM was higher in non-pregnant milk buffalos. In pregnant buffalo the amount of milk production is reduced due to lower amount of prolactin release and lower nutritional level because the fetus absorbs a major part on nutrition from mother. Moreover, low milk production is less prone to mastitis (Kader et al., 2002; Sederevicius et al., 2006) which was similar with this study. Besides, stage of lactation had no any effects on the development of SCM (Table 6) but in early and late lactation the prevalence was much higher than mid lactation. It was reported that 
buffaloes in the first stage of lactation (1-4 months) and the last part of dry period (7-9 months) were found more prone to mastitis (Kavitha et al., 2009).

In the present study, it was found that buffalos with history of per-parturient diseases had higher (23.08\%) prevalence of SCM (Table 7) in contrast with $19.30 \%$ of buffalos had without a history of per parturient disease, but there was no any significant difference. However, among the per-parturient diseases especially abortion case had the more chance to sub-clinical infection, but there was no any significant difference (Table 9). However, according to information from the farm owner, during winter season the clinical form mastitis was so higher than the other season but the possible causes was not investigated. Another study suggested that the higher incidence of mastitis was found in summer and rainy seasons (Sharma et al., 2012; Purohit et al., 2014). But another study suggested that highest incidence of clinical mastitis was recorded during December and January months followed by summer and least in rainy seasons (Ranjan et al., 2011).

Table 5. Effect of pregnancy status on SCM prevalence in buffaloes

\begin{tabular}{l|cccc}
\hline \multicolumn{1}{c}{ Pregnancy status } & $\begin{array}{c}\text { Number of animals at } \\
\text { risk }\end{array}$ & $\begin{array}{c}\text { Number of affected } \\
\text { animal }\end{array}$ & Prevalence (\%) & Overall difference \\
\hline Pregnant & 24 & 3 & 12.50 & $\mathrm{P}=0.2572$ \\
Non-pregnant & 46 & 11 & 23.91 & \\
\hline
\end{tabular}

Table 6. Effect of stage of lactation on SCM prevalence in buffaloes

\begin{tabular}{l|cccc}
\hline \multicolumn{1}{c}{ Stage of lactation* } & $\begin{array}{c}\text { Number of animals at } \\
\text { risk }\end{array}$ & $\begin{array}{c}\text { Number of affected } \\
\text { animal }\end{array}$ & Prevalence (\%) & Overall difference \\
\hline Early lactation & 23 & 5 & 21.74 & \\
Mid lactation & 22 & 4 & 18.18 & $\mathrm{P}=0.9565$ \\
Late lactation & 25 & 5 & 20.00 & \\
\hline
\end{tabular}

*Early lactation means up to 2 month post parturition, Mid lactation means $>2-5$ month post parturition, Late lactation means $>5$ month post parturition

Table 7. Effect of previous history of clinical mastitis on SCM prevalence in buffaloes

\begin{tabular}{c|ccccc}
\hline $\begin{array}{c}\text { Previous history of peri- } \\
\text { parturient disease }\end{array}$ & $\begin{array}{c}\text { Season of } \\
\text { year }\end{array}$ & $\begin{array}{c}\text { Number of animals } \\
\text { at risk }\end{array}$ & $\begin{array}{c}\text { Number of } \\
\text { affected animal }\end{array}$ & $\begin{array}{c}\text { Prevalence } \\
(\%)\end{array}$ & $\begin{array}{c}\text { Overall } \\
\text { difference }\end{array}$ \\
\hline Yes & Winter & 13 & 3 & 23.08 & \multirow{2}{*}{$\mathrm{P}=0.7586$} \\
No & - & 57 & 11 & 19.30 & \\
\hline
\end{tabular}

Table 8. Frequency of organism isolated from SCM of buffalo

\begin{tabular}{|c|c|c|c|c|c|c|c|}
\hline \multirow{2}{*}{$\begin{array}{l}\text { Total } \\
\text { sample }\end{array}$} & \multirow{2}{*}{$\begin{array}{l}\text { Organisms } \\
\text { grown }\end{array}$} & \multicolumn{2}{|c|}{$\begin{array}{c}\text { Staphylococcus aureus } \\
(\%)\end{array}$} & \multicolumn{2}{|c|}{$\begin{array}{l}\text { E. coli } \\
(\%)\end{array}$} & $\begin{array}{c}\text { Streptococcus sp. } \\
(\%)\end{array}$ & $\begin{array}{c}\text { Bacillus sp. } \\
(\%)\end{array}$ \\
\hline & & $\begin{array}{l}\text { Biochemical } \\
\text { test }+ \text { ve }\end{array}$ & PCR +ve & $\begin{array}{l}\text { Biochemical } \\
\text { test +ve }\end{array}$ & PCF & $\begin{array}{l}\text { Biochemical test } \\
+v e\end{array}$ & $\begin{array}{l}\text { Biochemical } \\
\text { test }+ \text { ve }\end{array}$ \\
\hline 14 & 13 & $13(100.00)$ & $8(61.54)$ & $9(69.23)$ & $8(61.54)$ & $3(23.08)$ & $4(30.77)$ \\
\hline
\end{tabular}

Table 9. Effect of previous history of other reproductive diseases on SCM prevalence in buffaloes

\begin{tabular}{l|llccc}
\hline Reproductive diseases & $\begin{array}{c}\text { Number of animals at } \\
\text { risk }\end{array}$ & $\begin{array}{c}\text { Number of } \\
\text { affected animal }\end{array}$ & Prevalence (\%) & $\begin{array}{c}\text { Overall } \\
\text { difference }\end{array}$ \\
\hline Abortion & 4 & 2 & 50.00 & \\
Uterine prolapse & 2 & - & 00.00 & $\mathrm{P}=0.2451$ \\
No other disease & 64 & 12 & 18.75 & \\
\hline
\end{tabular}

Among the total CMT-positive sample, 13 samples grown in culture medium and biochemically Staphylococcus aureus, E. coli, Streptococcus spp. and Bacillus spp. were indentified as $100.0 \%, 69.23 \%, 23.08 \%$ and $30.77 \%$, respectively (Table 8 ). However, among the cultured organism Staphylococcus aureus and E. coli were confirmed by PCR and it was about $61.54 \%$ in both cases (Figure 1). The PCR confirmation of Staphylococcus aureus and $E$. coli was much less than the biochemical test. For determining Staphylococcus aureus by PCR only coagulase-positive primer template was selected for Staphylococcus aureus. Coagulase-negative Staphylococcus also causes mastitis in bovine udder (Kudinha and Simango, 2002).
Among the four isolated bacterial population, Staphylococcus aureus was found to be the most prevalent compared to the other bacteria in the current study which also supports previous reports (Kudinha and Simango 2002; Suarzez et al., 2002) followed by E. Coli (69.23\%). The high prevalence of Staphylococcus aureus and E. Coli associated with SCM may be due to contamination of milk containers from the environment and also the poor hygienic condition during milking procedure. However, before milking there is no any practice to use antiseptic either for hand wash or udder wash (data not shown). This is the traditional practice of this area where only one time the buffaloes were milked at a day and the milking time was only very early in the morning. It was also found that after milking all buffalos went to river or a muddy area for rolling. 

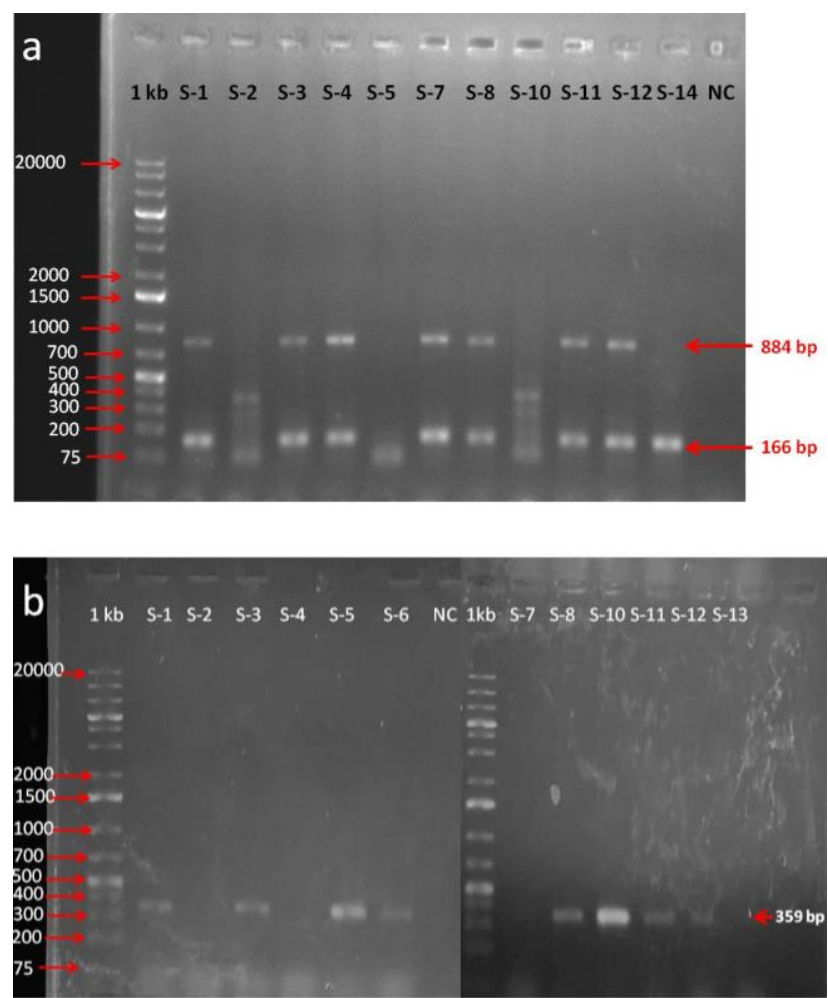

Figure 1. Expression of (a) E. coli and (b) Staphylococcus aureus DNA of CMT positive buffalo milk samples

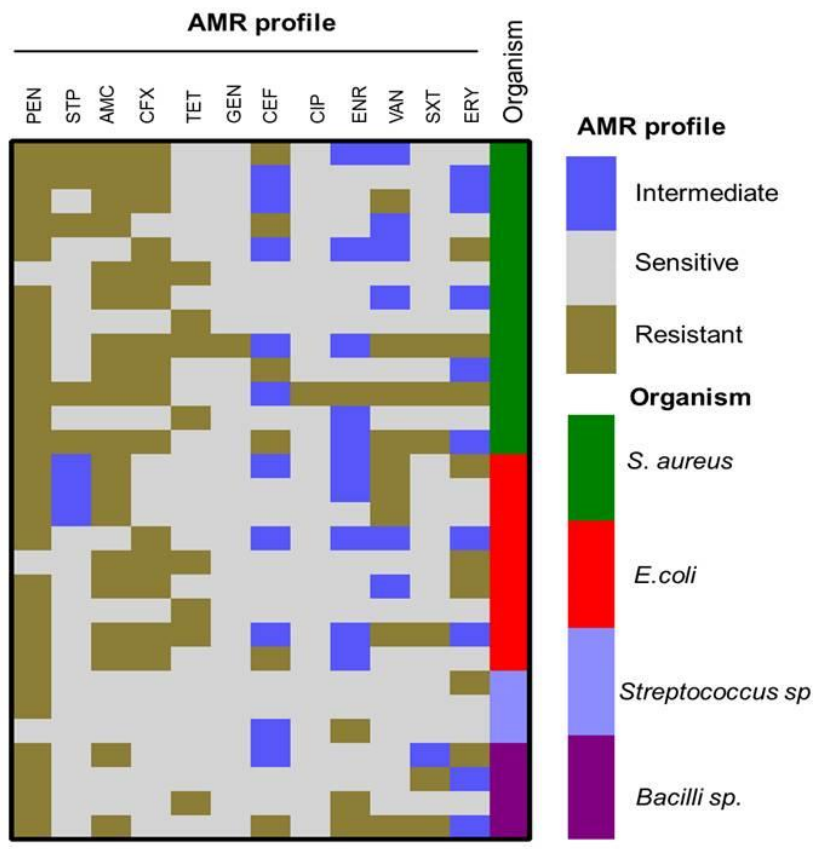

Figure 2. Heat map showing distribution of antimicrobial resistance phenotype of $S$. aureus $(\mathrm{n}=13), E$. coli $(\mathrm{n}=9)$, Streptococcus sp. $(\mathrm{n}=3)$ and Bacilli sp. $(\mathrm{n}=4)$ isolates from SCM affected buffalo. Each row represents one isolate. Where, PEN: Penicillin; STR: Streptomycin; AMC: Amoxicillin + clavulanic acid; CFX: Cefoxitin;

TET: Tetracycline; GEN: Gentamicin; CEF: Ceftriaxone;

CIP: Ciprofloxacin; ENR: Enrofloxacin; VAN:

Vancomycin; SXT: Sulfamethoxazole-trimethoprim; ERY: Erythromycin.
Standard antibiotic disc diffusion assay was applied for antimicrobial susceptibility test and it was presented in heat map (Figure 2). Twelve different antimicrobials disks were used in this experiment. All antibiotic disks were used to all isolated organisms. However, on average gentamicin and ciprofloxacin are more susceptible (92.31-100\%) to all 4 isolated organisms. The same result was found in another study in government buffalo farm at Bangladesh (Kisku and Samad, 2013) where gentamicin and ciprofloxaclin were shown moderate to high sensitivity. On the contrary, majority of the organisms were less sensitive to ceftriaxone, enrofloxacin, vancomycin and erythromycin. However, penicillin, amoxicillin, cefoxitin, tetracycline were more resistant to all four isolated organisms. Improper use of these antibiotics could lead to this resistance against these four isolated organisms. Therefore, this could be attributed to frequent use of these selected antibiotics in this selected areas were suggested previously (Jaims et al., 2002).

From this study it was concluded that buffalo's udder was very much resistance to SCM infection than cattle as a references and the udder management practice was very poor in the study area. Common antibiotics were resistance to isolated organisms from SCM cases.

\section{Acknowledgement}

The present research was financially supported by Ministry of Science and Technology, Government of the People's Republic of Bangladesh, under special allocation for science and technology of financial year: 2018 - 2019 (Grant Approval Code: SL\# 160, BS\# 214).

\section{Conflict of Interest}

No conflict of interest.

\section{References}

Abebe R, Hatiya H, Abera M, Megersa B, Asmare K. 2016. Bovine mastitis: prevalence, risk factors and isolation of Staphylococcus aureus in dairy herds at Hawassa milk shed, South Ethiopia. BMC Veterinary Research, 12 (1): 270.

Amin MR, Siddiki MA, Kabir AKMA, Faruque MO, Khandaker ZH. 2015. Status of buffalo farmers and buffaloes at Subornochar upozila of Noakhali district in Bangladesh. Progressive Agriculture, 26: 71-78.

Ansari-Lari M, Mohebbi-Fani M, Rowshan-Ghasrodashti A. 2012. Causes of culling in dairy cows and its relation to age at culling and interval from calving in Shiraz, Southern Iran. Veterinary Research Forum, 3(4): 233-237.

Baloch H, Rind R, Umerani AP, Bhutto AL, Abro SH, Rind MR, Abro R, Rizwana H, Kamboh AA, Baloch AK. 2016. Prevalence and Risk Factors Associated with Sub-Clinical Mastitis in Kundhi Buffaloes. Journal of Basic and Applied Science, 12: 301-305.

CLSI. 2010. Performance Standards for Antimicrobial Susceptibility Testing; Twenty-First Informational Supplement. Clin Lab Std Inst. CLSI document M100- S20 Wayne PA.

Das GK, FA Khan. 2010. Summer anoestrus in buffalo-a review. Reproduction of Domestic Animals, 45: 483-494.

DLS. 2015. Annual report on livestock. Division of Livestock Statistics, Ministry of Fisheries and Livestock, Farmgate, Dhaka, Bangladesh. 
El-Naker YF, Sayed-Ahmed M, Saad Z, Reiad E, Younis EE. 2015. Prevalence of Buffalo Mastitis in Dakahilia Governorate. Assiut Veterinary Medical Journal, 61 (145): 32-39.

Fareed SK, Memon KH, Kachiwal AB, Shajeela Azhar, Brula MI, Hasan MU, Ali M, Khan TA. 2017. Prevalence and economic losses of reproductive disorders and mastitis in buffaloes at Karachi, Pakistan. Indian Journal of Animal Research, 51 (6): 1130-1133.

Faruque MO, Hasnath MA, Siddique NN. 1990. Present status of buffaloes and their productivity in Bangladesh. AsianAustralian Journal of Animal Science, 3: 287-292.

Hamid MA, S Ahmed, MA Rahman and KM Hossain, 2016. Status of Buffalo Production in Bangladesh Compared to SAARC Countries. Asian Journal of Animal Science, 10: 313-329.

Huque QME, Borghese A. 2012. Production potentiality and perspective of buffalo in Bangladesh. Proceedings of the 15th AAAP Animal Science Congress, November 26-30, 2012. Thailand. pp. 244.

Inchaisri C1, Jorritsma R, Vos PL, van der Weijden GC, Hogeveen H. 2010. Economic consequences of reproductive performance in dairy cattle. Theriogenology, 74(5): 835-46.

Jaims EC, Montros LE, Renata DC. 2002. Epidemiology of drug resistance; the case of Staphylococcus aureus and Coagulase negative Staphylococci infections. Salud Publica Mex, 44 (2): 108-112.

Kader MA, Samad MA, Saha S, Taleb MA. 2002. Prevalence and etiology of sub-clinical mastitis with antibiotic sensitivity to isolated organisms among milch cows in Bangladesh. Indian Journal of Dairy Science, 55: 218-223.

Kavitha KL, Rajesh K, Suresh K, Satheesh K, Sundar NS. 2009. Buffalo mastitis risk factors. Buffalo Bulletin, 28:135-137.

Kisku JJ, Samad MA. 2013. Prevalence of sub-clinical mastitis in lactating buffaloes detected by comparative evaluation of indirect tests and bacteriological methods with antibiotic sensitivity profiles in Bangladesh. Buffalo Bulletin, 32 (4): 293-306.

Kudinha T, Simango C. 2002. Prevalence of coagulase-negative Staphylococci in bovine mastitis in Zimbabwe. Journal of the South African Veterinary Association, 73 (3): 62-65.
Millar BC, Jiru X, Moore JE, Earle JA. 2000. A simple and sensitive method to extract bacterial, yeast and fungal DNA from blood culture material. Journal of Microbiological Methods, 42(2):139-147.

Nahed MAS, Dalia K, Ahlam K, Abeer A. 2013. A biosecurity measures application with proper treatment to overcome the risk factors that limit effective control of subclinical mastitis in dairy buffalo farms-a field Study. Nature and Science, 11(7): 140-151.

Pankaj, Sharma A, Chhabra R, Sindhu N. 2013. Sub-clinical mastitis in murrah buffaloes with special reference to prevalence, etiology and antibiogram. Buffalo Bulletin, 32 (2): $107-115$.

Purohit GN, Gaur M, Shekher C. 2014. Mammary gland pathogenesis in parturient buffalo. Asia Pacific Journal of Reproduction, 3: 322-336.

Rabbani RA, Ahmad I, Lodhi LA, Ahmad N, Muhammad G. 2010. Prevalence of various reproductive disorders and economic losses caused by genital prolapse in buffaloes. Pakistan Veterinary Journal, 30(1): 44-48.

Ranjan R, Gupta MK, Singh KK. 2011. Study of bovi e mastitis in different climatic conditions in Jharkhand, India. Veterinary World, 4 (5): 205-208.

Sederevicius A, Balsyte J, Lukauskas K, Kazlauskaite, Biziulevicius GA. 2006. An enzymatic cow immunitytargeted approach to reducing milk somatic cell count: A comparative field trial. Food and Agricultural Immunology, 17: $1-7$.

Sharma N, Rho GJ, Hong YH, Kang TY, Lee HK, Hur TY, Jeong DK. 2012. Bovine mastitis: an Asian perspective. Asian Journal of Animal and Veterinary Advances 7(6): 454-476.

Siddiki MA, Amin MR, Kabir AKMA, Faruque MO, Khandaker ZH. 2015. Socio-economic status of buffalo farmers and the performances of buffaloes at Lalpur Upozila of Natore district in Bangladesh. Bangladesh Journal of Animal Science, 44(3):157-165.

Srinivasan P, Balachandran P. 2013. Prevalence and Etiology of Subclinical Mastitis among Buffaloes. Pakistan Journal of Biological Science, 16(23): 1776-1780.

Suarzez VH, Busetti MR, Miranda AO, Calvinho LF, Bedotti DO, Canovesio VR. 2002. Effect of infectious status and parity on somatic cell count and CMT in Pampinta dairy ewes. Journal of veterinary medicine. B, Infectious diseases and veterinary public health, $49: 230-234$. 